\title{
NTI FILE CODS
}

PNL -6922

TOXICOLOGY STUDIES OF LEWISITE AND SULFUR MUSTARD AGERTS:

GENETIC TOXICITY OF LEWISITE (L) IN CHINESE HAMSTER OVARY CELLS

FIHAL REPORT

R. F. Jostes, Jr., L. B. Sasser and R. J. Rausch

Pacific Northwest Laboratory

P. O. Box 999

Richland, WA 99352

May 31. 1989

Supported by

U.S. ARMY MEDICAL RESEARCH AMO DEVELOPMENT COMMAND

Fort Detrick, Frederick, MO 21701-5012

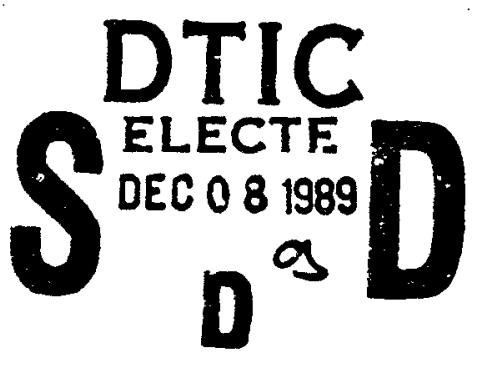

Army Project Order No. 84Pp4865

Contracting Officer's Representative

Jack C. Dacre, Ph.0., D.Sc.

Health Effects Research Division

U.S. Army Bicmedical Research and Development Laboratory

Fort Detrick, Frederick, Mo 21701-5010

Approved for public release; distribution unlinited

The findings in this report are not to be construed as an official Departicent of the Anny position unless so designated by other authorized documents. 
REPORT DOCUMENTATION PAGE

\begin{tabular}{|c|}
\hline $\begin{array}{l}\text { 18. REPORT SECURIT CLASSIFICATION } \\
\text { Unclass iffed }\end{array}$ \\
\hline 22. SECUATYY QLASSIFICATION AUTHC \\
\hline
\end{tabular}

2b. DECLASSIFACATION/DOWMGMOING SCHEDULE $---$

4. PETRORAING OREAUZATION REPORT NUMBER(S)

b. RESTACTIVE MARLINGS

3. DISTRLUTONIAVNLANTY OF REPONT

At :oved for public release; distribution unlimited

5. MOMTOAMG ORGAMLZATION REPORT NUMEER(S)

PNL-6922

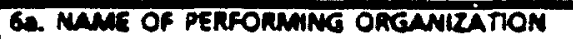

6b. OFFICE SYMCOT (I apolicatio)

Pacific Northrest Laboratory

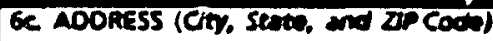
-
P.0. Box 999
Richland, WA 99352-0999

8h mane of Funding/sFonsolang

ongavizanon

U.S. Aniry Medical RAD Command
16. OFACE 5 YMIOL (i) apencente) -1-
9. PROCUREMTMT INSTRUMAMT DOENTFCATON MUMCKR

Anny Project Order 184 PP4865

10. SOURC Of FUNOWN WuMOEAs

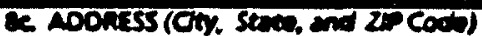

Fort Detrick

Frederick, MO 21701-5012

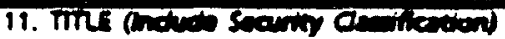

Toxicology Studies of Lewistte and Sulfur Mustard Agents: Genetic Toxicity of Lewistte (L) in Chinese Hamster Ovary Cells

12. Pisomal Aurmon(s)

R. F. Jostes, Jr., R. J. Rausch and L. B. Sasser

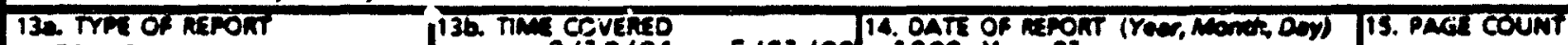
Final

16. Sumarimtant notation

Subtitle: Genetic Toxicity of Lewistte (L) in Chinese Hanster Ovary Cells

\begin{tabular}{|c|c|c|c|}
\hline 17. & \multicolumn{2}{|c|}{ cosati cooss } & \multirow{3}{*}{ 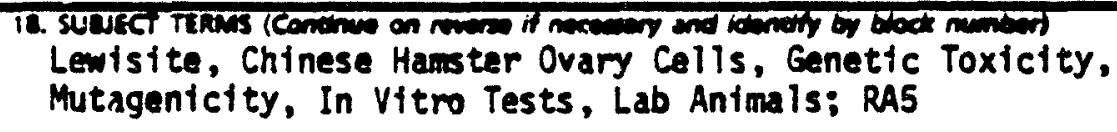 } \\
\hline FILD & GNoup & SUC-्करणि & \\
\hline 24 & 07 & & \\
\hline
\end{tabular}

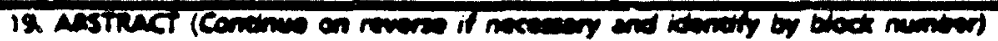

The cytotoxic, clastogenic and mutagenic effects of the arsentc containing vesicant,

Lewist te (L) [dichloro(2-chlorovinyl) arsine], have been Investigated using Chinese hamster ovary cells. One hour exposures to Lewistte were cytotoxic in uM anounts. The cell survival response ylelds a $\mathrm{D}_{37}$ of $0.6 \mathrm{HH}$ and an extrapolation number of 2.5 . The mutagentc response at the hypoxantnine-guantne phosportbosyl transferase (HGPRT) locus was sporadic and not signiffcantly greater than control values when cells were exposed over a range of 0.125 to $2.0 \mathrm{H}$. Sister chromatid exchange (SCE) Induction, a measure of chromosonal rearrangement, was makly posttfve over a range of 0.25 to 1.0 wil but the values were not signiffcantly greater than the control response. Chromosomal aberrations were fnduced at 0.75 and 1.0 uM in one expertment and 0.5 and 0.75 ul in another experiment. The induced values were significantly greater than the control values. Lewlst te appears to be cytotoxic and clastogentc in our investfgations tut SCE and mutation at the HGPRT locus are not stgniffcantly greater than control values. Lewisita toxictty was in som ways simtlar to radiontmatile chemtcals such as bleometo.

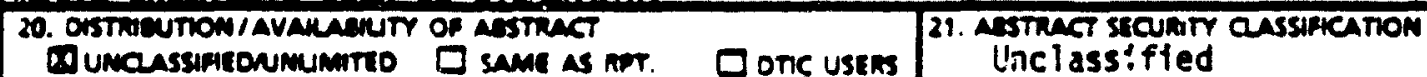

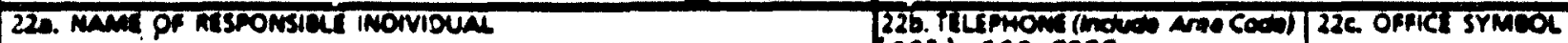
Mary Frances Bostlan.

301) $663-7325$

SGRD-RMT-S 
Opinions, interpretations, conclusions and recommendations are those of the author and are not necessarily endorsed by the U.S. Army.

Where copyrighted material is quoted, permission has been obtained to use such material.

Where material from documents designated for limited distribution is quoted, permission has been obtained to use the material.

Q. Citations of commercial organizations and trade names in this report do net constitute an officiai Department of the Anmy endorsement or approval of the products or services of these organizations.

In conducting research using animals, the investigatoris) adhered to the "Guide for the Care and Use of laboratory Animals," prepared by the Comittee on Care and Use of laboratory inimals of the Institute of Laboratory Animal Resources, Mational Research Council (NIH Publication No. 86-23, Revised 1985).

For the protection of human subjects, the investigator(s) have adhered to policies of applicable Federal Law 45CFR46.
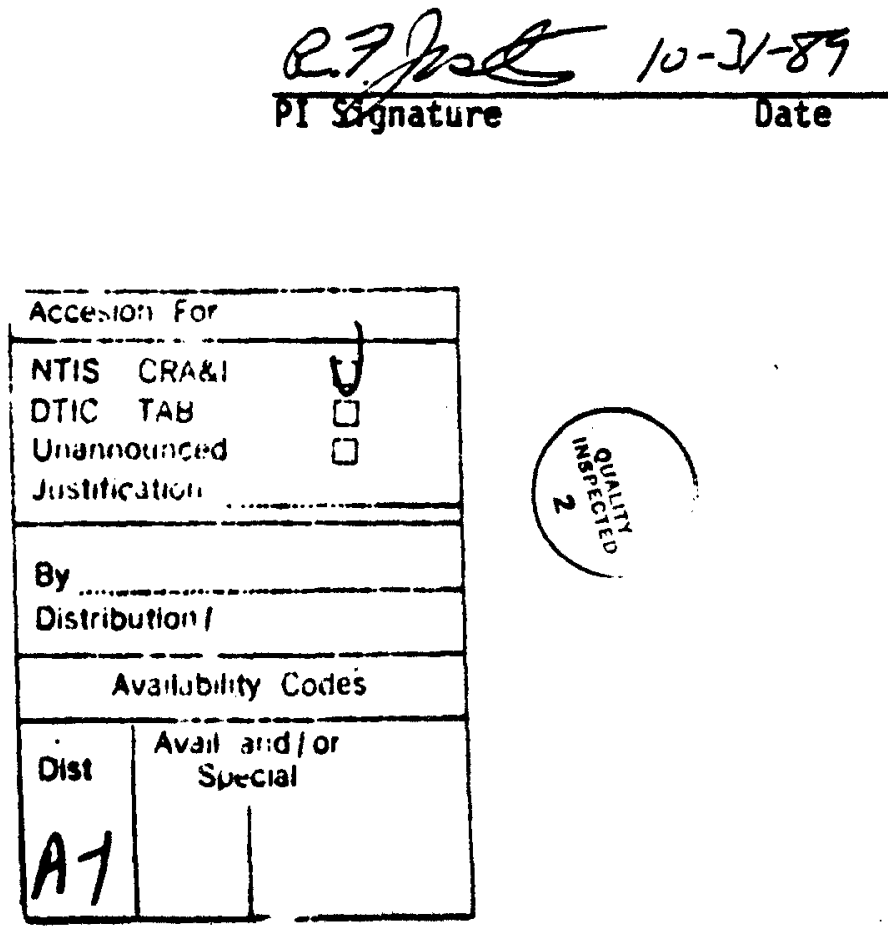
$D$

Chemicai warfare agents present an obvious risk to individuals suffering acute exposure, but they may also present long-term environmental or occupational health hazards for workers in operations involving these chemical agents. Occupational health standards have not been established for Lewisite (L) [dichloro(2-chlorovinyl)arsine] a potent vesicant which reacts with sulfhydryl groups of proteins through its arsenic group. Lewisite is used in a number of research laboratories, stored in depot sites throughout the country and occasionally transported to distant sites. The destruction of current stockpiles of Lewisite by the U.S. Army in the near future could create additional environmental and occupational risk. To establish a database for setting environmental and occupational standards, we conducted studies to evaluate the toxicity, mutagenicity, and reproductive effects of Lewisite using in vitro and in vivo study systems.

The cytotoxic, clastogenic mutagenic effects of Lewisite in Chinese hamster ovary cells were investigated and are described in this report. One mutation assay and two cytogenetic assays were used in this study. The mutation assay utilized the hypoxanthine-guanine phyosphoribosyl transferase (HGPRT) locus (6-thioguanine resistance). The two cytogenetic analyses were chronosomal aberration analysis, measurement of chromosome damage, and sister chromatid exchange (SCE), a measurement of chromosome rearrangement.

The CHO cells were exposed in the test system for 1 hour, then washed and culturert for an additional 20-30 hours, depending on the assay to be used. The total number of mutant colonies were determined and the mutation frequency was calculated. Chromosome aberracions were scored using 100 metaphases per dose and SCE per cell were calculated. (SDW)

One hour exposures to Lewisite were cytotoxic in $\mu$ M anounts. The cell survival response yielded a $\mathrm{O}_{37}$ of $0.5 \mathrm{\mu M}$ and an extrapolation number of 2.5. The mutagenic response at the HGPRT locus was sporadic and not significantly greater than control values when cells were exposed over a range of 0.12 to $2.0 \mathrm{MH}$. Sister chromatid exchange (SCE) induction, a measure of chromosomal rearrangement, was weakly positive over a range of 0.25 to $1.0 \mathrm{wH}$ but the values were not significantly greater than the control response. Chromoscmal aberrations were induced at $0.50,0.75$ and $1.0 \mathrm{mM}$ in one experiment and 0.50 
and $0.75 \mu M$ in another experiment. The induced values were significantly greater than the control values. Lewisite appeared to be cytotoxic and clastogenic in our investigations but SCE and mutation at the HGPRT locus were not significantly greater than control values. Lewisite toxicity was in some ways similar to radionimetic chemicals such as bleomycin. 
TABLE OF CONTENTS

Page

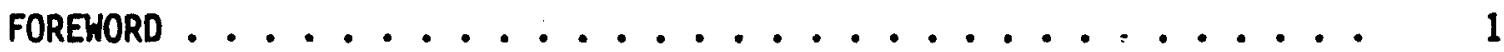

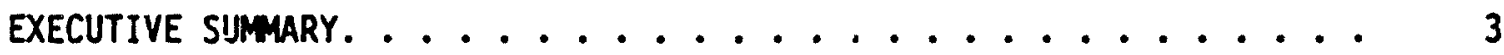

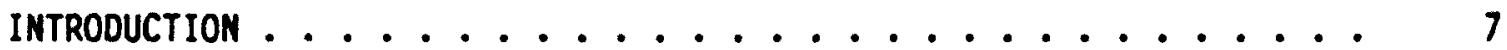

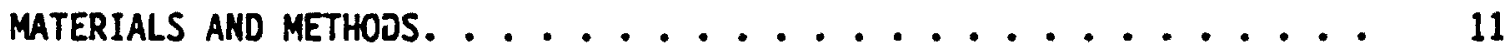

Lewisite. . . . . . . . . . . . . . . . 11

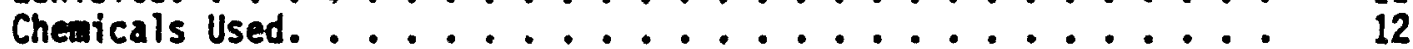

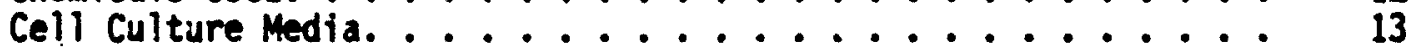

Identification of Cell Line ............... 13

In Vitro Assays .................... 13

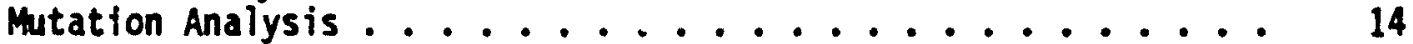

Cytogenetic Analysis. ................... 14

Statistical Analysis...................... 15

RESULTS. . . . . . . . . . . . . . . . . . . 17

Cytotoxicity. . . . . . . . . . . . . . . 17

Mutation Results. ................ 17

Sister Chronatid Exchange ............... 17

Clastogenic Effects ................. 22

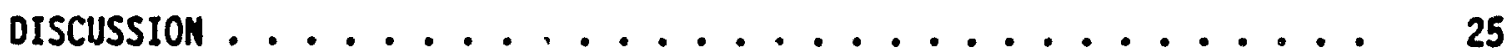

LITERATURE (ITEJ . . . . . . . . . . . . . . . . . 27

PERSONHEL LIST . . . . . . . . . . . . . . . . . . . 29

QUALITY ASSURANCE STATEMENT. . . . . . . . . . . . . . . 30

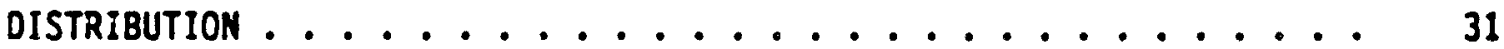

LIST DF FIGURES

Figure Page

1 Fraction of cells surfiving Lewisite treatnent . . . . . 18

2 Fraction of cells surviving Lewisite treationt in the

presence of $S 9 . \ldots . \ldots 19$ 


\section{LIST OF TABLES}

Table

Page

1 Relevant Chemical and Physical Data for Lewisite, Dichloro(2-chlorovinyl)arsine. .......... 8

2 Lewisite Induced Mutations at the HGPRT Locus in CHO Cells - 20

3 Lewisite Induced Sister Chromatid Exchange in $\mathrm{CHO}$ Cells. . . 21

4 Lewisite Induced Chromosome Abberations in CHO Cells . . . 23 


\section{INTROOUCTION}

Chenical warfare agents present an obvious risk to individuals suffering acute exposure but they may also present long-term environmental or occupational health hazards for workers in operations involving these chemical agents. Lewisite [dichloro(2-chlorovinyl)arsine], one of two major vesicant agents, presents a potential for accidental or occlipational exposure because it is used in a number of research laboratories, stored in depot sites throughout the country and occasionally transported to distant sites. In addition, stockpiles of Lewisite are scheduled for destruction by the U.S. Army in the near future, creating an additional potential for environmental and occupational exposure. Although considerable information is known concerning the acute effects of Lewisite, few data are available on its longterm hazards. Segments of the population that may be particularly sensitive to its toxicity include the chronically ill, the young and old, and the unborn. It is this concern that has prompted these studies to identify the potentially toxic, mutagenic and reproductive effects of Lewisite and to establish a database for the development of hazard evaiuations and occupational health standards for this chemical.

Lewisite is a highly toxic chemical vesicant. Unlike the strong alkylating vesicant sulfur mustard, Lewisite reacts with the sulfhydryl groups of proteins through its arsenic group (Cassarett and Doul1, 1986). In the presence of water or alkalies, Lewisite hydrolyzes to form Lewisite oxide, which is non-volatile and insoluble in water. Although few data are available, Lewisite oxide is generally thought to be a weaker vesicant (Gates et al., 1946; but its toxicity has yet to be detemined. Relevant chemical and physical data for Lewisite are sumarized in Table 1.

A comprehensive review which sumarized the chemical and toxicity data of Lewisite acquired during World War I and World War II was published in 1946 (Gates et ai., 1946). This review compared known human and animal data and concluded that sufficient. toxicologic data were avallable for the determination of military usage. Lewisite exposure is characterized by inmediate onset of pain, unlike the action of sulfur mustard in which pain may be delayed. The mucus membranes of the respiratory and gastrointestinal 
TABLE 1. Relevant Cheaical and Physical Data for Lewisite, Dichloro(2-chlorovinyl) arsined

Cas A:

RTECS :

Structural formula:

Molecular weight:

Density at $20^{\circ} \mathrm{C}$ :

State:

Vapor pressure at $20^{\circ} \mathrm{C}$ :

Decomposition temperature:

Solubility in water:

Hydrolys is

Rate:

Products:
$541-25-3$

CH2975000

Cl- $\mathrm{CH}=\mathrm{CH}=\mathrm{AsCl}$

$207.3 \mathrm{~g}$

$1.888 \mathrm{~g} / \mathrm{mi}$

Derk, oily liquid

(stable in steel and glass)

0.394 m $>100^{\circ} \mathrm{C}$

Very slightly soluble

Rapid

Chlorovinyl arsenous oxide, HCl

(in acid solutions)

Acetylene, sodium arsenate

(in alkaline solutions)

aRosenblatt et al. 1975

tracts are particularly sensitive to Lewisite danage. Lewisite is not only lethal vesicant but is also a systemic toxin; the liver, kidneys, gall sladder, blle duct and other organ systems are vulnerable to danage if absorption occurs (Cameron et al. 1946).

Exposures to Lewisite vapor produces edema of the respiratory tract and accumulation of pleural fluid (Gates, et al., 1946). Skin lesions resulting from contact with liquid Lewisite involve the rapid formation of an erythematous area, subsoquent vesication and penetration of subcutaneous tissue so that edeara and necrosis are evident. Man wes less sensitive to skin lesion induction than the dog or rabbit. Systeatic intoxication was evident in the dog a few hours following application of Lewisite (Gates et al., 1946). Although sufficient anatomical lesions to characterize the imediate cause of death were not apparent. it was reported that fluid losses due to changes in capillary permability did cause remarkable decreases in blood volume. Comparisons of toxic effects of Lewisite and sulfur oustard in dogs and rabbits indicated that Lewiste was nore damaging to the skin and was more likely to induce systemic poisoning than was sulfur mustard. 
Few data are available to evaluate the potentid chronic effects of Lewisite other than information based on anecdotal evidence from war use. based on one incidence of accidental exposure to a soldier's leg. Lewisice is considered a suspect carcinogen in man (Krause and Grussendorf, 1978). Workers of a Japanese factory producing mustard and Lewisite agents during World War II had a high mortality rate due to respiratory and gastrointestinal cancers (Wada et al., 1968; Yamakidc ot al., 1985). These workers were potentially exposed to unknown quantities of both sulfur mustard and Lewisite; therefore, it is not possible to implicate lewisite as a carcinogen because of possibie confounding effects of the carcinogen sulfur mustard.

Virtually no data were found on the mutagenicity of Lewisite in tile literature. Auerbach (1947) found no zutagenic response in the fruit fly exposed to Lewisite and Loveless (1951) reported normal celiular division in root tips exposed to aqueous solutions of Lewisite. The teratogenic potential of Lewisite was studied by Hackett et al. (1987) in rats and rabbits using a segment II teratology protocol. Rats were exposed to 0.5 , 1.0 or $1.5 \mathrm{mg} / \mathrm{kg}$ Lewisite via gastric intubation from 6 to 15 days of gestation (dg) and fetuses were examined on $\mathrm{dg} 20$. No evidence of a teratogenic response to Lewisite was observed. Likewise, fetal development of the rabbit exposed to 0.07 to $0.6 \mathrm{mg} / \mathrm{kg}$ Lewisite between 6 and $19 \mathrm{dg}$ was net affected even though maternal nortality was induced. These results suggest that Lewisite is not teratogenic in the rat or ihe rabbit after short term exposures since fetal effects were observed only at dose levels that induced maternal toxicity.

It is of interest that many of the symptoms of Lewisite and arsenic intoxication are similar (severe inflamation of the gastrointestinal tract with electrolyte disturbances and ulceration and perforation of membranes) (NAS, 1977; and raise the possibility that the toxicity of Lewisite may result from its arsenic group. In alkaline jolutions, Lewisite may hydrolyz to form acetylene and sodium arsenate. Leonard and Laumerys (1980) reviewed the carcinogenicity, teratogenicity and mutagenicity of a wide variety of arsenic compounds. Arsenic, as sodiun arsenate or arsenite, is knom to be eubryotoxtc and teratogenic in a number of animal spectes (Leonard and Laumerys, 1980). In a comparison of Lewisite and sodiu arsenite toxicity in the rabbit following intravenous adainistration, Inns et al. (1988) reported 
that the $L D_{b 0}$ is of sodien arsenite and Lewisite were not sinilar $(7.6$ and $1.8 \mathrm{mg} / \mathrm{kg}$, respectively). Furtherwore, significant differences in tissue arsenic content and pathology mere reported for the two chemicals.

Very little information is available on the effects of Lewisite using in vitro, mamalian cell systems. However, the mutagenicity of arsenic compounds in vitro has been reviewed (Leonard and Louwerys, 1980). In general all of the arsenic compounds investigated in mamalian cell systems produced chromosomal aberrations. No information is available for atation induction in mamalian systems, although arsenic compounds were analyzed in bacterial systems and some were mutagenic mile others were not. We repart here on the cytotoxicity, eutagenicity: and also the clastogenicity of Lewisite using Chinase hasster ovary (CHO) cells. 


\section{MATERIALS ANO METHODS}

\section{Lewisits}

Procurement and Characterization

A shipment of 25 al of dichloro(2-chlorovinyl)arsine (! ewisite, Agent L) was received from the U.S. Aray Medical Research Institute of Chemical Defense (USAMRICD) on 7 March 1985. The chenical (Lot Mo. L-U-4273-CTF-N) was prepared by distillation on 30 September 1984 at the Cheaical Research and Development. Center (CRDC). The agent was analyzed by nuclear aagnetic resonance ( $\mathrm{H}-\mathrm{i}$ and $\mathrm{C}-13$; $\mathrm{CROC}$ SOP No. 8-1-83-1, Annex $\mathrm{F}$ ) at the Research Directorate, CRDC. Results of the analyses, expressed as calculated weight percent, were 95.8 and 4.0 for trans and cis iscevers of dichloro(2ch!oroviny l) arsine, respectively, and 0.2 for unknown compounds.

The Lewisite was divided into two equal portions, pipetted into $30-\mathrm{ml}$ Wheaton vials, sealed and stored in secondary unbreakable containers in refrigerats. storage at ${ }^{\circ}{ }^{\circ} \mathrm{C}$. To comply with $600 d$ Laboratory Practices requirements, PNL requested that USAMICD retain an aliquot of this lot of Lewisite.

Lewisite was analyzed on 20 January 1986 to detect the presence of cammon impurities, such as Lewisite oxide and the cis-trans iscaners of bis(2chlorovinyl)chloroarsine and tris(2-chlorovinyl)arsine (Rosenblatt et al., 1975). Measuresent of the ultraviolet absorption spectrun of the sample in isooctane revealed that the spectre and the absorptivity of the material at $215 \mathrm{~nm}$ agreed with published values in the literature (Rewick, et al.. 1986; Mohler and Sorge, 1939) and did not indicate the presence of ultravioletsbsorbing compounds other than Lewisite. This conclusion was supported by our results from gas-chromatographic analyses of the sample following derivatization with 2-mercaptoethanol.

\section{Selection and Characterization of Diluent}

Lewtsite is relatively insoluble and aiso is rapidly hydrolyzed in water; therefore, absoiute ethanol (EtOH) was employed as the diluent for sosing solutions in this study. 
Lewisite in EtOH was assayed by gas chromatography, using a capillary colum and flawe-ionization detection. Lewist te was prepared by the addition of 2-mercaptoethanol; the reaction, which proceeds at roca teaperature, my be written:

$$
\mathrm{ClCH}=\mathrm{CHASCl}_{2}+2 \mathrm{HSCH}_{2} \mathrm{CH}_{2} \mathrm{OH} \longrightarrow \mathrm{ClCH}=\mathrm{CHAS}\left(\mathrm{SCH}_{2} \mathrm{CH}_{2} \mathrm{OH}\right)_{2}+2 \mathrm{HCl}
$$

In the procedure developed for the anaiysis, Lewisite samples were diluted 1:10 with isooctane prior to analysis. For the assay, 1.0 11 of the sample was diluted with 0.5 wl of a solution containing $112 \mathrm{ng}$ of 1-chioronaphthalene and $5584 \mathrm{ng}$ of 2-mercaptoethanol/pl in isooctane contained in a 1.5 in automatic sampler vial with a Teflon-lined, crimped-top cap. The colum (JeN Scientific, DB-5) temperature program was $90^{\circ} \mathrm{C}$ for 5 min $\left(5^{\circ} / \mathrm{ail}^{\mathrm{i}}\right.$ ) to $140^{\circ} \mathrm{C}, 20^{\circ} /$ min to $300^{\circ} \mathrm{C}$ and $300^{\circ} \mathrm{C}$ for 40 min. A Hewlett-Packard $5840 \mathrm{~A}$ gas chromatograph and a $7672 \mathrm{~A}$ automatic sample changer were used.

The results were within acceptable linits of analytical error for concentrations greater than $0.5 \mathrm{mg} / \mathrm{ml}$. As the Lewisite concentrations in the solutions decreased, the assay results becase less acceptable. The mothod was not sufficiently sensitive to detect concentrations of Lewisite beiow 0.1 $\mathrm{mg} / \mathrm{ml}$. Lewisite was stable in EtOH at concentrations above the detection limit for at least one day; all exposures mere conducted within 24 hours of preparation of Lewisite solutions:

Chemicais Used

Dilutions of the Lewisite were made up in absolute (punctilious) ethanol (EtOH - U.S. Industrial Chemical Co.). A new bottle of ethanol was used for each experiment. Ethyl methanesulfonate (EMS - Siga lot 195F-0226) was used as a positive control for mutation and sister chromatid exchange (SCE) studies. EMS proved inadequate as a positive control for aberration analysis and bleomycin (Sigma Lot 137F-0888) was substituted. All Eus dilutions were made up in absolute ethanol. 6-aninocrysine (6-AC: Aldrich lot 1092797) was used as a positive control for materfals that required 59 activation. 6-AC was solubilized in dinothylsulfoxide (ouso: American Type Culture, Lot 129341). Metabolic activation was accomplished using Litton Bionetics rat 
liver S9 preparation lot 107420 . The 6-thioguanine (6-TG: Sigma lot $15 f-$ 4023), used as a selecting chemical in the hypoxanthine-guanire phosphoribosyl transferase (HGPRT) mutation assay, was made up in sterile water as a 3 $\mathrm{mM}$ stock solution and used at a final concentration in mediun of $30 \mathrm{~m}$.

5-Bramo-2'-deoxyuridine (Brd Urd: Sigm lot 156F-0767 and 135F-0089), Hoechst dye (Sigma lot $106 \mathrm{~F}-0458$ and $125 \mathrm{~F}-3538$ ), and Giensa stain (Gurr's improved 9.66 lot $\$ 772201$ ) were used to differentiate sister chromatids. The Sorensen's buffer used in this techinique was ade up as a $10 x$ solution ( $A$ and $B$ stock). Stock $A=9.07 \mathrm{~g} \mathrm{~K} \mathrm{H}_{2} \mathrm{PO}_{4}$ in $100 \mathrm{al} \mathrm{H}_{2} \mathrm{O}$; Stock $B=9.47 \mathrm{~g} \mathrm{Na}_{2} \mathrm{HPO}_{4}$ in $100 \mathrm{ml} \mathrm{H}_{2} \mathrm{O}$. The final working solution was $10 \mathrm{ml} A$ and $10=18$ brought up to 100 in?s total with $\mathrm{dH}_{2} \mathrm{O}$ and the $\mathrm{PH}$ was adjusted to 6.8 .

\section{Cell Culture Madia}

F12 andiun supplemented with 54 fetal bovine serum (fbs) was used for routine cell culture. F12 adium - hypoxanthine (-HX) suppleicented with 5 s dialyzed fetal bovine seru (dfbs) was used for wutant selection.

\section{Identification of Cell Lime}

The cells used in this study wre designated $\mathrm{CHO} / \mathrm{C} 18$ which was a subclone of CHO used for mutation analysis (Jostes et al., 1980). These cells have been subsequently alneained in liquid nitrogen and cultured in F12 aedium suppleanted with 5 f fetal bovine serum. Cell identification was routinely verifted using chromosom analysis. Chromosom analysis included showing that the man chromsom numer was 21 and that the karyotype was consistent with CHO cells.

\section{In Vitro Assays}

One mutation assay and two cytogenetic assays mere used in this study. The mutation assay utilized the KGPRT locus (6-thioguanine resistance). The two cytogenetic analyses mere chromoscanal aberration analysts (a masurement of chromosom deage) and SCE (a masurement of chromosome rearrangement). The experimental design for each was as follows: 
Mutation Analysis

In addition to the test compound, the CHO/HGPRT mutation assay contained the following elements; a positive control (EMS); a promutagen (6-AC) which required metabolic activation and a solvent control (EtOH) which served as a negative control. Three concentrations of the test compound were assayed in replicate or triplicate. CHO cells mere treated in 75 cm tissue culture flasks. Cells $\left(0.5-1.0 \times 10^{6}\right.$ per flask) were plated into $10 \mathrm{ml}$ F12 medium with 54 fetal calf serum (Jcs) and were incubated for 15-24 hours before exposure. The test compound was diluted in EtCH and a standard volume (50 al) was added to $10 \mathrm{al}$ of F12 medium minus serum for cell exposure. Directacting mutagens were added to 10 al of F12 medium - fobs and incubated at $37^{\circ} \mathrm{C}$ for 1 hour 5 min.

Rat liver microsomes ( 59$)$ were used in same experiments to activate proastagens. In this case the 59 and associated cofactors were added to the odium just before treatment.

After treatment cultures wee washed 3 times with saline $G$ and fresh $F 12$ + 5* $\mathrm{fbs}$ was added to the cultures. The cells were then incubated for an additional 20-30 hours before trypsinization to alleviate possible trypsin effects. After trypsinization the cells wee plated for initial survival (day 1) and for phenotypic expression (6-10 days). At the end of the expression period the cells mere trypsinized and replaced into F12 - HD + 54 debs for determination of plating efficiency and $5 \times 10^{4}$ cells/mall were plated into 3, 6-mil plates containing F12 -HX, 30 6-T6 and 54 debs for selection of mutant colonies.

After colony formation the plates wee fixed, stained, and counted. The total number of mutant colonies and the plating efficiency was determined at each treatment. The mutation frequency was then calculated by dividing the total number of mutant colonies by the cells plated into 6-TG corrected for plating efficiency.

Cytogentic Analysis

Treatment protocols were as described previously for the mutation analysis. After treatment the cells wee cultured for at least 24 hours in

14 
F12 medium supplewented with 5 t fbs for aberration analysis. If the chromosomes mere to be scored for SCE, 10 H BrdUrd was present in the mediun after treatment. After approximately 24 hours colcemid was added at a final concentration of $0.08 \mathrm{mg} / \mathrm{ml}$. Metaphase cells were collected by the "shake" method and the suspended cells were centrifuged, swelled, fixed and burst onto aicroscope slides. Cells were prepared for aberration analysis by staining in 5\& Giensa. Chromosones mere prepared for SCE analysis by a modification of the wethodology of Perry and Wolff (1974).

\section{Statistical Analysis}

Chromosowe aberrations wre scored using 100 wetaphases per dose. In aberration studies each cell was evaluated as an individual treatwent and means and standard errors are calculated within each experiment. Standard error is used because of the high numer of naught values in each treatment and the poisson nature of aberration distribution. The standard error was determined by the formula: square root of the nean number of aberrations divided by the square root of the number of metaphases evaluated (Bradley et al. 1981).

SCE were scored and the data is expressed as SCE/Ce11. Analysis of 30 wetaphases/treatwent was made and significant differences were determined using the wo conventional standard deviations (Renington, 1970).

Criteria for a positive mutation response were evaluated according to the genetox reports of Bradley et al.. (1981). That is, any response $3 \times$ the appropriate spontaneous value was taken to be positive. 
RESULTS

\section{Cytotoxicity}

Figure 1 presents the $\mathrm{CHO}$ cell survival response (day 1) for 1 hour Lewisite exposures as determined by colony formation in two experiments. Using the data from experiment $B$ a $D_{37}$ of approximately $0.5 \mu \mathrm{M}$ - - wisite and an extrapolation number of 2.5 was derived. When the cells were exposed in the presence of $\$ 9$ microsomal fractions, the survival was enhanced suggesting that the 59 itself interferes with Lewisite toxicity (Figure 2).

Mutation Results

Initially, a dose range of 0.12 to to 1.0 M was selected for mutation analysis (Table 2, experiment $A$ ). This represents essentially the first decade of survival. Because the metabolic requirements of Lewisite are unknown 59 aicrosomal fractions were included in a replicate set of exposures. In this experiment the only wutation frequency that exceeded control values was at the highest exposure dose without $\$ 9(1.0 \mu \mathrm{M})$. Accordingly, a higher dose range of 0.5 to $2.0 \mathrm{~m}$ was selected for the second experiment (Table 2, experiment B). In this experiment the only value above spontaneous was the $1.0 \mathrm{MH}$ exposure with $\mathrm{S9}$. In both cases in which the frequencies were above spontaneous values the variation of the control and treated frequencies suggest that they are not significantly different.

\section{Sister Chroantid Exchange}

Table 3 presents data which show a small increase in chromosomal rearrangement (SCE) at all of the dose levels investigated with the exception of $0.5 \mathrm{mM}$ (experiment $\mathrm{C}$ ) and $0.25 \mathrm{MH}+\mathrm{Sg}$ (experiment 0 ). In no case however, were the treatment values significantly greater than the spontaneous values as determined by standard deviations. Furthermore, no value was greater than 564 above the spontaneous value nor was a concentration related increase observed over at least 3 concentrations. 


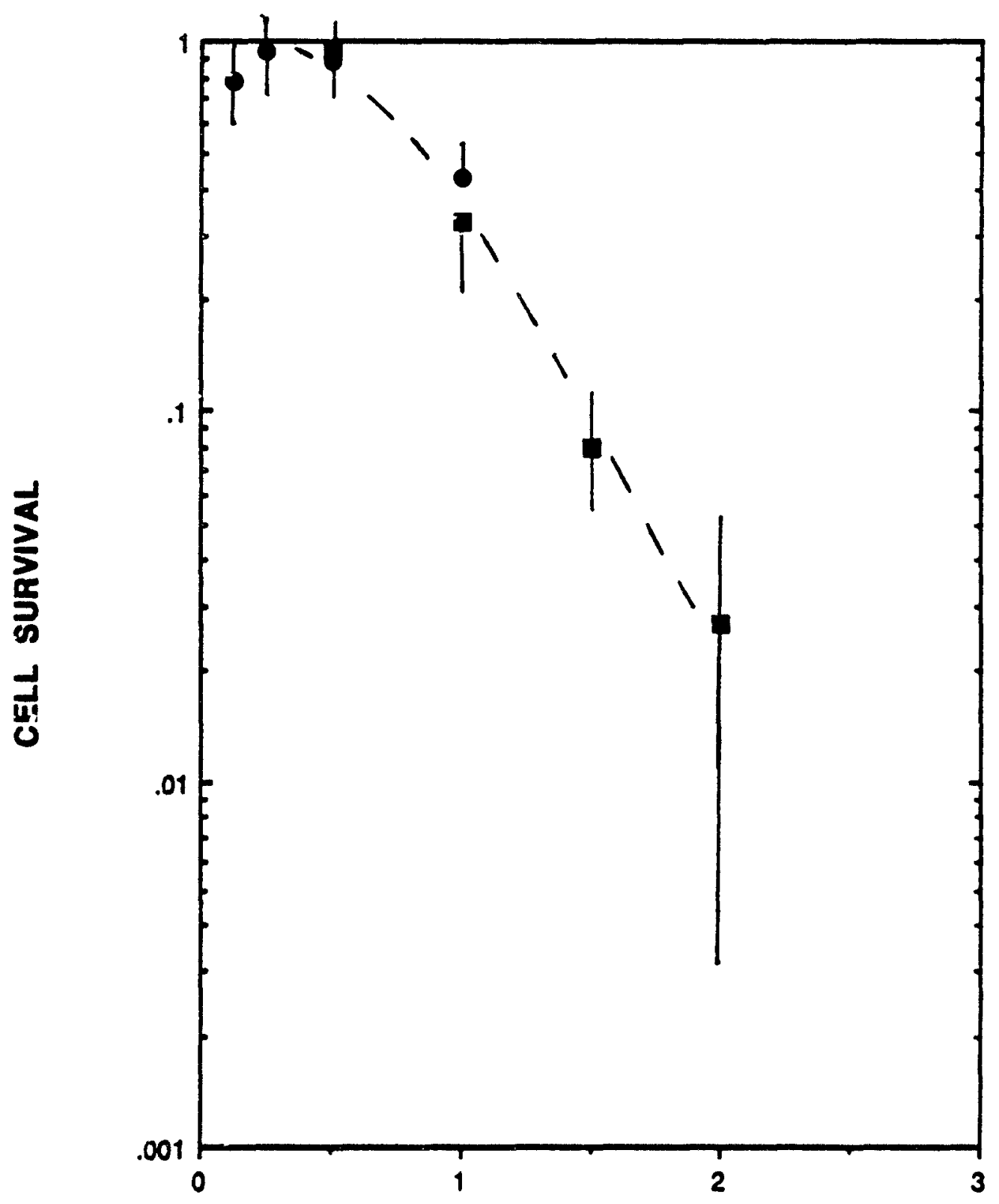

UM Lewialto

Figure 1. Fraction of cells surviving Lewistite treatment (day 1). Circles are from experiment $A$ and squares are from experiment B. The line was dram by eye to the data irom experibent B. 


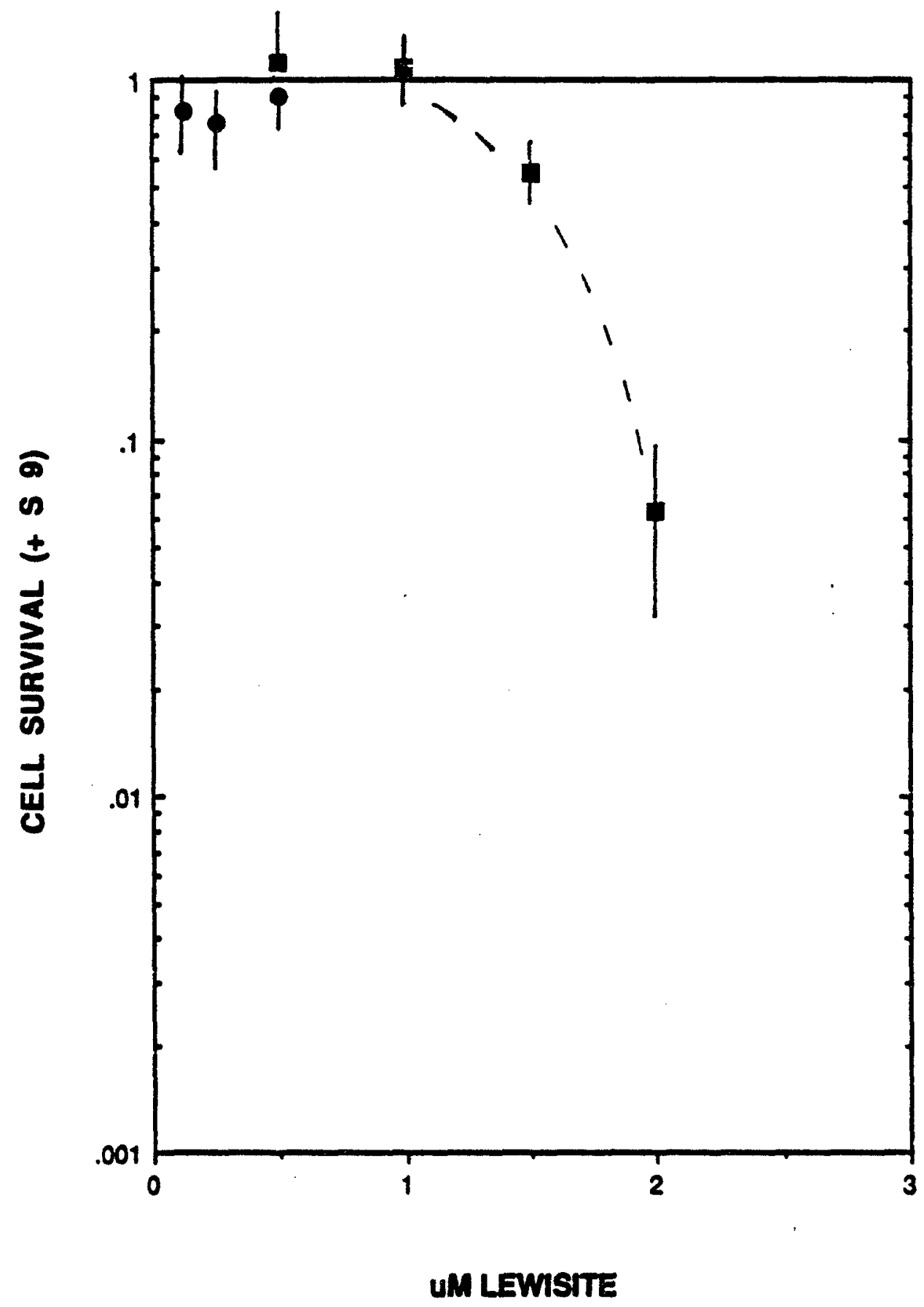

Figure 2. Fraction of cells surviving Lewisite tratas.te in the presence of 59 (day 1). Circles are experiment $A$ and squares are experiment B. The line was drawn by eye to the data from experiment $B$. Note the increase in survival compared to that without S9 (see figure 1). 


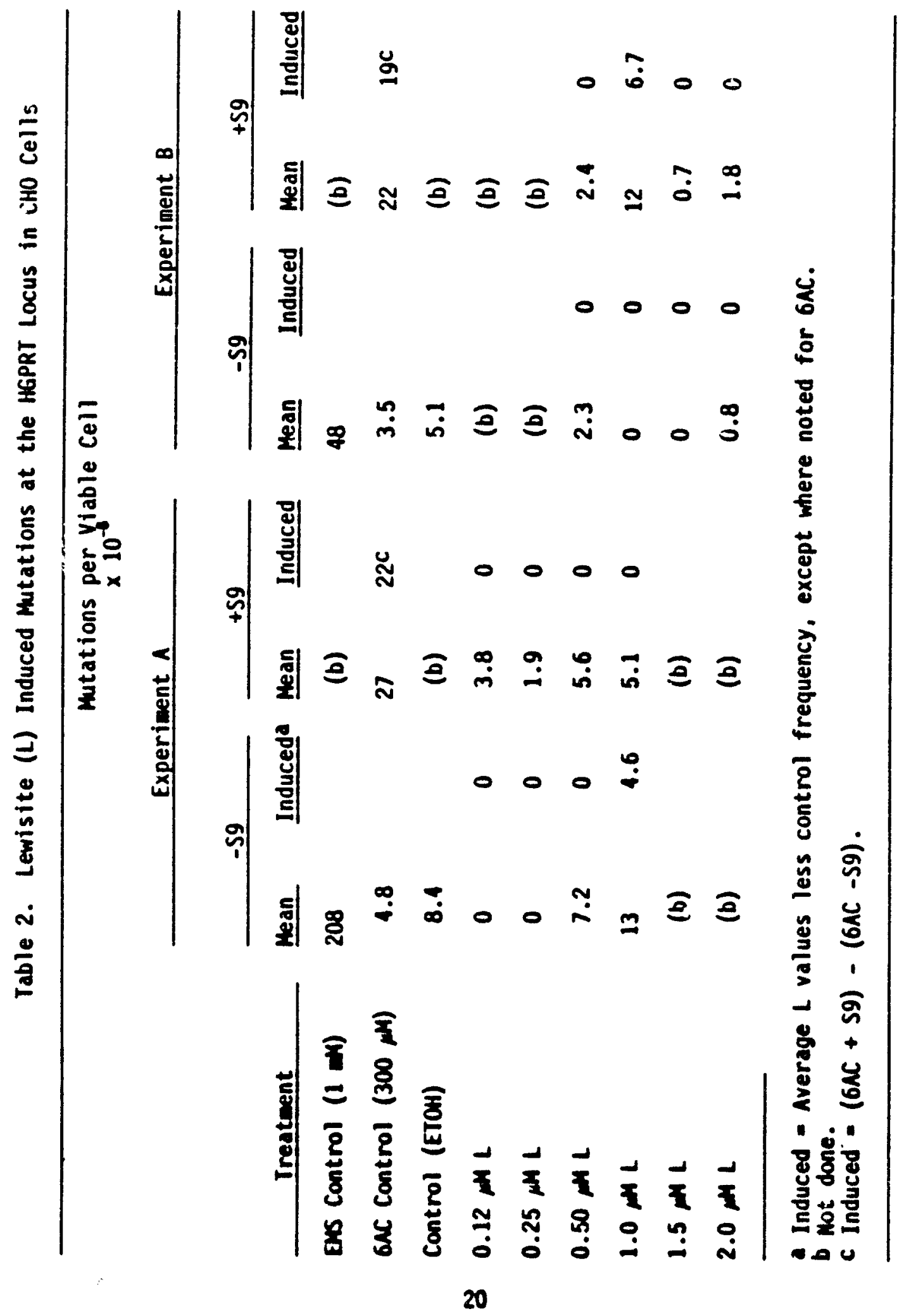




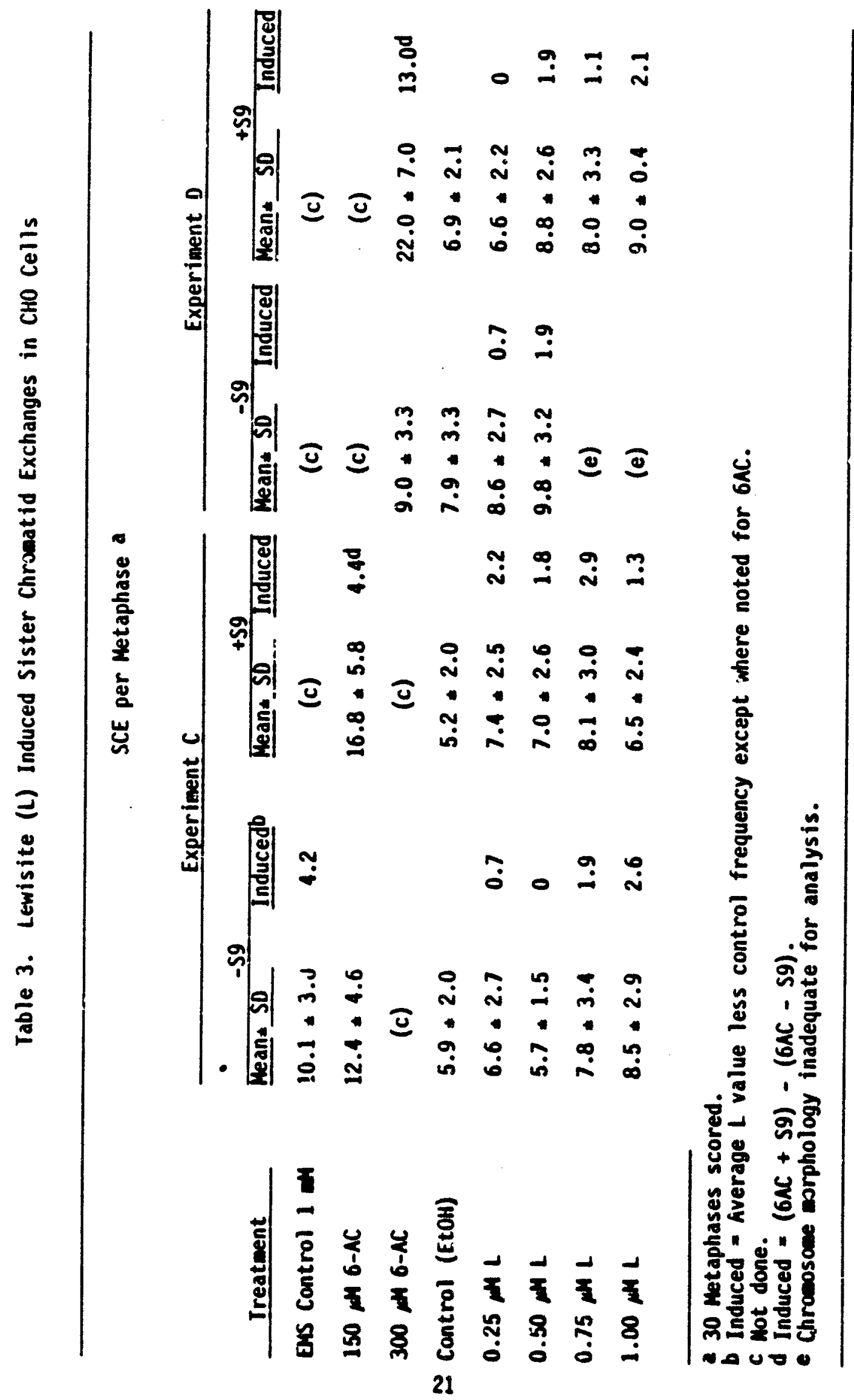




\section{Clastogenic Effects}

A dose rarge of 0.25 to $1.0 \mu$ Lewisite was selected for the aberration experineits based on survival results. This represents a survival range of 30 to 100 percent. Table 4 presents data from two experiments. In both experiments a threshold was seen above which aberration frequencies were significantly greater than control values. When cells were exposed to Lewisite in the presence of $S 9$ (experiment $E$ ) a significant increase was not apparent. Because of this result and a sinilar inhibition of cytotoxicity (Figure 2) we did not include $S 9$ in experiment $F$. The absolute toxicity (as judged by zetaphase recovery and aberration induction) was greater in experiment $F$. Significant increases $(P<0.05)$ in aberrations were observed at $0.5,0.75$, and $1.0 \mu \mathrm{M}$ Lewisite in experiment $E$ and 0.5 and $0.75 \mu M$ Lewisite in experiment $F$ as judged by standard error. 


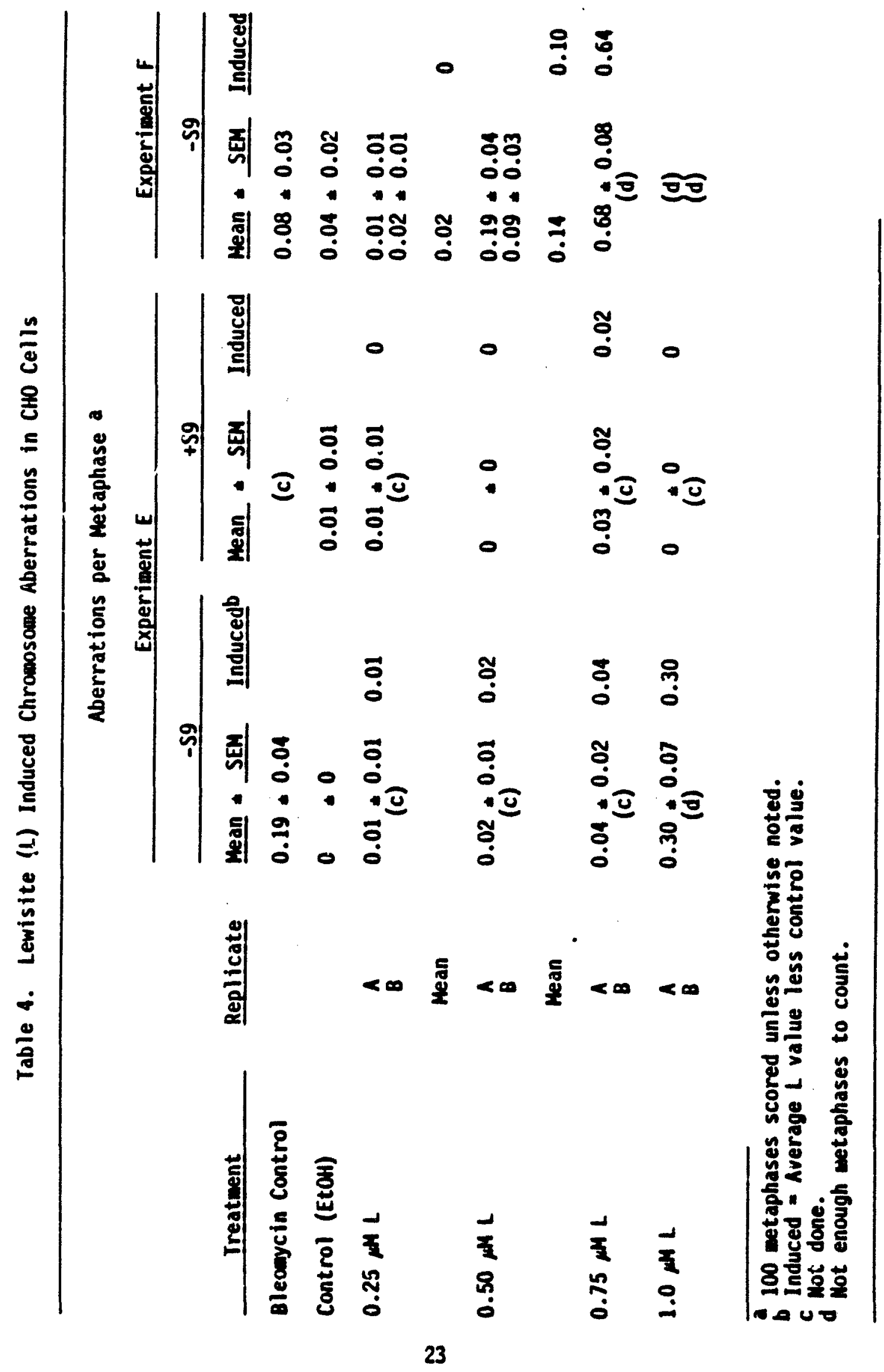


Lewisite induced chronosonal aberrations at nicronolar exposure levels. Convarsely, SCE were not observed in statistically significant numbers. In this regard, Lewisite is sinilar to blecoycin, a radionimetic, antineoplastic agent. One interpretation of this observation would be that the action of the two agents might be similar. We have noted in this report that significant levels of mataions are not observed at the HGPRT locus. It is tempting to suggest that Lewisite affects the DMA in such a way that all "hits" are lethal. It is knom, however, that bleomycin is a weak mutagen at the HGPRT locus and a strong mutagen at the L5178Y TK locus. A popular interpretation of this observation is that lesions induced by bleanycin affect many loci (mitilocus deletions, translocations) and that tile first lethal gene lies close to the HGPRT gene but is further rewoved from the TK locus in L5178Y cellis.

In any case, chromosomal aberrations are often lethal events and no doubt contritute to cell death after Lewisite exposure. Whether or not the agent is mutagenic may require investigations at other loci, such as the L5178Y TK system. In at least one gene situation, CHO - KGPRT, Lewisite is not mutagenic over the first decade of survival. 


\section{LITERATURE CITED}

Auerbach, $i$ and J.M. Robson. 1947. Tests of chemical substances for mutagenic action. Proc. Royal Soc. of Edinburah 62B: 284-291.

Bradley, M.O., B. Bhuyan, M.C. Francis, R. Langenbach, A. Peterson and E. Huberman 1981 Mutagenes is by chemical agents in V79 Chinese hauster celli: a review and analysis of the literature - A report of the gene-tox program. Mutat. Res. 87:81-142.

Cameron, G.R., H.M. Carleton and R.H.O. Short. 1946. Pathological changes induced by Lewisite and Allieú Compounds. J. Pathol. Bacteriol. 58, 411-422.

Cassarett, L.J. and J. Doull. 1986. Toxicology. The Basic Science of Poisons, 3rd Ed., MacMillan Publishers, Men York, NY.

Gates, M., J.H. Willians and J. A. Zapp. 1946. Aresenicals. Chemical Warfare Agents and Related Chemical Probleas,. Sumary Technical Report of Division 9, National Defense Research Conittee, Vol. 1, Parts I and 11. pp. 83-114. Washington, D.C.

Hackett, P.L., L. B. Sasser, R.L. Romerein, J.A. Cushing, R. L. Buschbon, and D. R. Kalkwarf. 1987. Teratology studies on Lewisite and sulfur mustard agents: Effests of Lewisite in rats and rabbits. AD-A187495. U.S. Army Medical Research and Development Comand, Fort Detrick, Frederick, Mo.

Inns, R.H., J.E. Bright and T.C. Marrs. 1988. Comparative acute systemic toxicity of sodium arsenite and dichloro(2-chlorovinyl)arsine in rabbits. Toxicology 51: 213-222.

Jostes, R.F., K.M. Bushnell and W.C. Deway 1980 X-ray fintuction of 8azaguanine-resistant mutants in sjnchronous Chinese haster ovary cells. Radiat. Res. 83:146-161.

Krause, H. and E.I. Grussendorf. 1978. Syntony of Bowen's disease and Lewisite scar. Hautarzt 29: 490-493.

Leonard, A. and R.R. Laumerys. 1980. Carcinggenicity, teratogenicity and mutagenicity of arsenic. Mutat. Res. 75: 49-62.

Loveless, A. 1951. Qualitative aspects of the chemistry and biology of radicanimetic (mutagenic) substances. Nature 167: 338-342.

Mohler, H. and J. Sorge. 1939. Chentcal warfare materials. XII. Light abscrption by nose and throat, lung and skin poisons in ultraviolet of short wave length. Helv. Chim. Acta 22: 235-239.

National Acadery of Science. 1977. Madical and Biologic Efferts of Envirommental Pollutants, Arsenic. Washington, D.C. 
Perry, P. and S. Wolff. 1974. New Giensa wethod for the differential staining of sister chromatids. Nature 251: 156-158.

Reaington, R.D. 1970. Statistics with Application to the Biological and Health Sciences. 1970 Prentice Hall, Engiewood Cliff, M.

Rewick, R.T., M.L. Schumacher and D. L. Haynes. 1986. The ur absorption spectra of chemical agents and stimulants. Appl. Spectroscopy 40: 152-150.

Rosenblatt, D.H., T.A. Miller, J.C. Dacre, I. Muul, and O.R. Cogley (eds.). 1975. Proble definition of potential enviromental pollutants. II. Physical. chearical, toxicological and biological properties of 16 substances. In: U.S. Army Medical Bioengineering Research and Development Technical Report 7509. Fort Detrick, Frederick, Mo.

Hada, S., Y. Mishiooto, M. Miyanishi, S. Kabe, and R.H. Miller. 1968. Mustard gas as a cause of respiratory neoplasia in aan. The Lancet 7753: 1161-1163.

Yamakido, M. and T. Shigenobu. 1985. Tha causes of death in the retired workers of Okuno-Jim poison gas factory. Jpn. J. Med. 34: 311-322. 


\section{PERSONNEL LIST}

Function

Study Director

Facility Manager

Solution Preparation and Analysis

Fxposures

Laboratory Evaluation

Project Manager

Study Dates:

Initiated: 28 April 1987

Completed: 15 September 1987

Data are property of the U.S. Army and will be archived under the Army's direction at approved facilities.

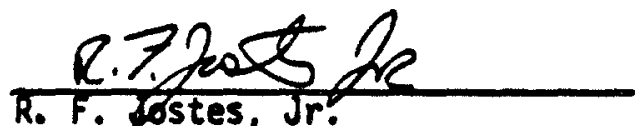

$\frac{10 \cdot 3 /-89}{\text { date }}$ 


\section{Qublity Asurance Strment}

Listed below are the pheses and/or procedures inchuded in the study described in this report which were reviewed by the Qunlity Assurance Unit specifically for this soudy and the dares the reviews were performed and findings reparted to manapement. (All fintings were reparted to the study director or his desigmes at the time of the review.)

Phase/Procedure Reviowed

Cell Harvatings

Cell Replating

Crranomone Dropping

Final Repart
Dere Finding Suberitued in Writing to

Sudy DirectodMrangement

- Cell doaing was conduced in the limied chemical surety facility.

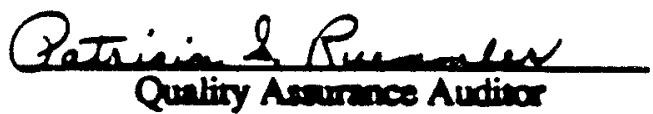

$10 \log 19$

$706 / 87$

706887

$922 / 87$

$10 / 16 / 89$
$6 / 26 / 87 \& 7 / 01 / 87$

$9,03 / 87$

6/15-16/89 \& $9 / 6-7 / 89$

. 


\section{OISTRIBUTION}

\section{OFFSITE}

Comander (25)

U.S. Arwy Bionedical Research and Development Laboratory

Attn: SGRD-URZ-RA

Fort Detrick

Frederick, mo 21701-5010

Comander (2)

U.S. Army Modical Research and Development Comand

Attn: S6RD-PLE

Fort Detrick

Fredertck, in 2170i-5012

Comander (2)

U.5. Arny Hedical Research Institute of Chemical Defense

Attn: SGRD-UV-ZB

Aberdwen Proving Grounds, mo 21010-5425
Comander (3)

U.S. Arny Medical Research and Developrent Comand Attn: SGRD-RHI-S

Fort Detrick. Frederick, it 21701-5012

Chenical Effects Information Center (1)

Oak Ridge Mational Laboratory P.0. Bax $X$

Oak Ridge, Tn 37831

\section{QASITE}

DOE/RIchlani Operations Office

E.C. Morman/O.L. Sours

Pacific Morthmest Laboratory

Publishing Coordination

Technical Report Files (5)

R.F. Jostes, Jr. (3)

L.8. Sasser (3) 